\title{
4-H Projects: Frequently Asked Questions ${ }^{1}$
}

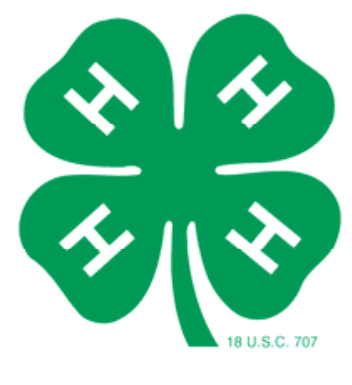

Joy C. Jordan ${ }^{2}$

\section{What is a 4-H project?}

A "project" is a series of learning experiences of six hours or more within an area of interest.

\section{Must all 4-H'ers enroll in projects?}

Yes. The key learning experience for 4-H youth is through "projects."

\section{When do youth enroll in projects?}

Annually. Every year, youth in 4-H Clubs choose the projects they wish to explore during the coming year. Ideally, youth should enroll and receive their project manuals within the first month of the new 4-H Club year. Then the enrollment is entered into the Florida 4- $\mathrm{H}$ Enrollment System.

4-H'ers participating in organized special-interest, day camp, or classroom projects directed by adults are enrolled in the project through their group registration, and their enrollment is likewise entered in the Florida 4- $\mathrm{H}$ Enrollment System annually.

However, in most counties, a 4-H member can select, enroll in, and complete projects at any time throughout the year.

\section{How many projects can 4-H'ers enroll in during the year?}

As many as they think they would like to do. There is no statewide policy setting limits on 4-H project enrollment. In Florida, youth in 4-H clubs enroll in an average of three projects a year. It is recommended that younger 4H'ers select only one or two projects at a time.

\footnotetext{
1. This document is 4-H S FS101.14, one of a series of the Florida 4-H Program, Florida Cooperative Extension Service, Institute of Food and Agricultural Sciences, University of Florida. Published November 2006. Please visit the 4-H Website at http://4h.ifas.ufl.edu/Curriculum/index.htm.

2 Joy C. Jordan, Associate Professor in the Department of Family, Youth and Community Sciences, Institute of Food and Agricultural Sciences, University of Florida, Gainesville, FL, 32611.
}

The Institute of Food and Agricultural Sciences (IFAS) is an Equal Employment Opportunity - Affirmative Action Employer authorized to provide research, educational information and other services only to individuals and institutions that function without regard to race, creed, color, religion, age, disability, sex, sexual orientation, marital status, national origin, political opinions or affiliations. For information on obtaining other extension publications, contact your county Extension Service office. The Florida 4-H Program is the youth development program of the Florida Cooperative Extension Service/Institute of Food and Agricultural Sciences/University of Florida/Larry R. Arrington, Dean. 


\section{What do I get if I do complete the project?}

Most counties' project recognition begins with certificates of completion. Project reports submitted to the county may also be reviewed and evaluated against set standards for additional recognition and awards including ribbons, pins, monetary scholarships, or gifts from specific project donors.

Statewide, at age fourteen, youth may submit a cumulative record of their 4-H projects, called a 4-H Portfolio. This portfolio will be evaluated, and outstanding youth will be selected for opportunities to compete for state-sponsored national trips and college scholarships.

\section{When is a project completed or over?}

The project is over or "completed" when a 4-H'er has completed the activities he/she has chosen and submitted completed project reports for club leader review or county recognition. Projects are designed to be completed within the year; however, there is nothing preventing a child from working at his or her own pace. The child may simply "re-enroll" in the same project until the experiences have been completed and the project report has been turned in. Some youth elect to enroll in the same project year after year, identifying new goals for themselves annually.

\section{Is being an officer in a club a project?}

No. Youth in 4-H clubs are provided many additional learning and leading opportunities, such as being club officers. This is not a project. Enrolling in and completing a series of learning activities and experiences in the Leadership Project, however, counts as a 4-H project.

\section{Is club community service a project?}

No. Each 4-H club in Florida is expected to complete at least one community service activity per year. If the club decides to do a roadside clean-up, for instance, this is simply a club community service activity. A single activity is not a project.

Service Learning/Citizenship projects are available that the club, as a whole, can elect to complete. These projects guide youth individually or as group through a more comprehensive process of planning, conducting, and evaluating their service to others or the community.

\section{What is expected of me when I enroll in a project?}

There are certain essential steps to most 4-H projects. Generally speaking, you will:
- Set goals and identify things you want to learn or accomplish in the project.

- Participate in learn-by-doing activities within the project.

- Participate in supporting events and activities within the project area to show, demonstrate, or exhibit the knowledge, skills or products resulting from your project.

- Reflect and record your experiences from these activities as you complete the project work, using the 4-H Project Report.

- Gain recognition for your accomplishments before your peers and others in your community.

\section{Do I have to do a demonstration to be in a project?}

No. Enrolling in a project does not require you to present a demonstration to your peers or others of what you know or have learned. However, this is a strongly encouraged experience. It is the first step to building the personal skills and confidence that $4-\mathrm{H}$ promotes.

Demonstrating - showing and telling others about your project and sharing how to do something-is a simple way to share your enthusiasm for a project you enjoy.

Demonstrations also do not have to take place at competitions, although 4-H does offer these opportunities for youth when they are ready.

\section{Do I have to be in a project to participate in a competitive demonstration or judging contest?}

Yes. In order to participate in a competitive demonstration or a contest supporting a project area, you must be enrolled in that project. The project materials and the learning experiences in the project give you the knowledge, skills, and experiences you need to be prepared for the competitions that provide opportunities to demonstrate your scholarship in your chosen project area.

\section{Under what circumstances are Livestock Judging or Consumer Choices considered projects?}

Livestock judging and consumer choices are two competitive events designed to support youth enrolled in either livestock projects (i.e. beef, sheep, swine, etc) and consumer education projects. Livestock judging and Consumer Choices have state-supported curricula that provide group/leader-directed experiences for conducting special interest project groups for youth not enrolled in the individual $4-\mathrm{H}$ projects.

If youth participate in these experiences through an organized group-enrolled/reported special-interest group, they may count as projects. 
Youth who are already enrolled in selected related projects, such as beef, sheep or other livestock projects, should report livestock judging as a project activity, not as a separate project. Youth who are already enrolled in consumer-related projects should do the same.

\section{Resources}

Further information on 4-H curricula, projects, events, recognition opportunities, and guidelines is available at http://www.florida4h.org. 